Eight years ago, it was a profit-making contract research organization (CRO) that counted every major pharmaceutical firm among its clients. It was Europe's largest contract testing organization, a public company with nearly $\$ 100$ million annual turnover and a string of institutional investors. Now, less than five years later, Huntingdon Life Sciences (HLS) has been hounded out of the UK, forced to relocate and reinvent itself.

HLS's demise followed a 1997 TV documentary exposé of animal cruelty by a few rogue staff members who were subsequently fired. Vociferous protests ensued, followed soon after by a protracted campaign of violence (spitting, kicking, telephone threats, hate mail, razor blades, parcel bombs, car torching, acid attacks, baseball-bat beatings-you get the picture). These were directed by extremists first at HLS management and staff, and later at the company's financial backers and clients.

Soon after, the captains of industry, big banks, investors, trade bodies, and research charities all abandoned HLS to its fate. Only when the UK government stepped in and found a US backer-the Stephens Group-did it begin to look like HLS could survive. A year later, Stephens has now also divested itself of its shares and the \$24 million loan (although apparently for commercial reasons and not as a response to the bullying and threatening of US Animal Liberation Front extremists). As Nature Biotechnology went to press, the company plans to relist in New York as Maryland-based Life Sciences Research (p. 111).

Many erstwhile clients and backers attempted to rationalize their decision to pull out, stating that they could no longer support HLS research on moral grounds. Others were more honest, saying that they placed personal safety above that of their investments. A third group, including most of the UK scientific community, scientific journals, regulators, and government, has been conspicuously silent. The image-conscious UK government, in particular, did much too little, much too late to save HLS. Granted, it is about to come up with a law allowing company directors not to disclose their home address - which might mitigate the threat of personal violence-but it has done precious little else. Indeed, according to HLS's former chief executive, Christopher Cliffe, the Blair government was duplicitous in its dealings with Parliament, suppressing from public view reports that might have helped HLS's case.

What kind of message is that to send out to the biotechnology community? Biotechnology companies themselves are particularly vulnerable to the kind of vicious intimidation that has been directed at HLS and its employees. They rely on the goodwill and support of groups such as investors and market-active multinationals whose understandable gut instincts are to protect their established reputations and maintain their profitable status quo. In essence, the violent activists who have taken such a dislike to HLS could equally justifiably turn their attentions on any company dealing with biological materials in a way they did not approve. If clinical research organizations need to be wary, why not companies working with stem cells, human tissues, GM livestock, GM plants, or virtually any other organism?

HLS is a legitimate business. Indeed, its activities are demanded by the law. All new medicines must be animal-tested before human use. Without organizations like HLS, they would not be approvable under current legislation. It is thus disappointing that the UK government did not act more visibly and decisively to counter the propaganda campaign mounted by the extremists.

If governments are serious about encouraging biotechnology as a source of economic development, employment, and innovative medicines and products, they need to show greater resolve in protecting lawful businesses that operate at the edge of the general public's understanding of life. The UK government should have acted swiftly to stop the brutality and intimidation at HLS. This would have been right, if perhaps unpopular. In explaining its actions, it could have passed on some of its deep understanding of the complex issues to its electorate and thereby perhaps shown real leadership.

\section{Nothing succeeds like failure}

In Mel Brooks' film The Producers, two impresarios (played by Zero Mostel and Gene Wilder) seek a theatrical flop to use as part of a tax scam. They back a tasteless off-Broadway production, Springtime for Hitler, written by a maniac Nazi sympathizer, fully expecting the show to close before the first-night interval. Unfortunately, the production succeeds resoundingly and our heroes are ruined.

Much the same situation faces the monoclonal antibody developer Imclone (p. 111). Unless Imclone's monoclonal antibody drug, cetuximab, bombs in its next colorectal cancer trial, the company could be in real trouble. Cetuximab has attracted a good deal of critical acclaim. It has proved effective in tackling colorectal cancer. One particularly difficult set of patients are those who have already failed to respond to the cytotoxic drug irinotecan. When such patients receive cetuximab as well as irinotecan, nearly a quarter of them respond positively. Results such as these convinced Bristol-Myers Squibb last year to buy a $20 \%$ stake in Imclone for $\$ 1$ billion, with the promise of milestones and royalties adding another $\$ 1$ billion if the drug reaches the market.

The only problem is that, according to the US Food and Drug Administration, Imclone has not shown clinically that irinotecan is really necessary in the combination treatment. From Imclone's perspective, irinotecan is indispensable. Without it (or some other compound), cetuximab falls squarely under IP held by Genentech on monoclonals against colorectal cancer (according to TheStreet.com). With its own colorectal antibody in development, though, Genentech has no incentive to grant Imclone a license at anything approaching reasonable terms.

The FDA argues that Imclone needs to show that cetuximab is less effective on its own than in combination with irinotecan. Imclone has conducted a small trial of the antibody alone, but the results were not significantly different from the performance of the combined regimen. Now Imclone must institute a larger trial. If cetuximab alone proves to be a wonderful drug, that could be bad news for Imclone and BMS but very good news for colorectal cancer patients and Genentech. 